\title{
Photostabilization of sunscreens by incorporation of tea as the external phase
}

\author{
Fotoestabilização de protectores solares por incorporação de chás como fase externa
}

\section{Margarida Pereira $^{1}$, Nicole Pereira ${ }^{1}$, Catarina Rosado ${ }^{1}$, Camila Areias de Oliveira ${ }^{2}$, Daniela D'Almeida \\ Peres $^{2}$, Maria Eduarda Araújo ${ }^{3}$, Maria Valéria Robles Velasco², André Rolim Baby², Joana Portugal Mota $^{1^{*}}$ and Tânia Santos Almeida ${ }^{1^{*}}$}

${ }^{1}$ CBIOS - Research Center for Biosciences and Health Technologies, Universidade Lusófona, campo Grande, 376, 1749-024

Lisboa, Portugal

${ }^{2}$ Faculdade de Ciências Farmacêuticas, Universidade de São Paulo, Av. Prof. Lineu Prestes, 580, Bloco 15, 05508-900, São Paulo, Brasil

${ }^{3}$ Centro de Química e Bioquímica, Faculdade de Ciências, Universidade de Lisboa, Campo Grande, 1749-016 Lisboa, Portugal and Departamento de Química e Bioquímica, Faculdade de Ciências, Universidade de Lisboa, Campo Grande, 1749-016 Lisboa, Portugal

Email: tania.almeida@ulusofona.pt

*Shared senior authorship

\begin{abstract}
The use of isolated ultraviolet (UV) filters in photoprotective formulations creates products with limited protection against radiation, emphasising the need to develop formulations containing UVA and UVB filter combinations. However, most of the formulations developed to include both filters are unstable as a result of this combination, as well as by exposure to UV radiation. It is, therefore, crucial to include additives that enable photostabilization. Tea is the second most widely consumed beverage in the world and represents a good source of bioactive compounds, particularly polyphenols, which provide antioxidant activity. In the present work formulations containing green tea or black tea, as well as the sunscreens avobenzone (UVA sunscreen) and octilmetoxinamato (UVB sunscreen), were developed and evaluated in order to develop new and effective photostable formulations providing broad spectrum photoprotection. These formulations have been developed with complete replacement of the external phase of the oil in water $(\mathrm{O} / \mathrm{W})$ emulsion by these teas. The results showed that both teas presented photostabilizing capacity, particularly for green tea in the storage conditions at room temperature and at $5{ }^{\circ} \mathrm{C}$, and black tea for the samples stored at $40{ }^{\circ} \mathrm{C}$.
\end{abstract}

Key-words: green tea, black tea, photoprotective formulations, photostabilizing capacity, octyl methoxynnamate, avobenzone

\section{Resumo}

A utilização de filtros ultravioleta (UV) isolados em formulações fotoprotetoras origina produtos com proteção limitada contra as radiações, evidenciando a necessidade de desenvolver formulações contendo a associação de filtros UVA e UVB. No entanto, a maioria das formulações desenvolvidas por combinação destes filtros é instável como consequência desta combinação, bem como pela exposição à radiação UV. Assim, é fundamental associar activos que permitam a sua fotoestabilização. O chá é a segunda bebida mais consumida em todo mundo e representa uma fonte nutritiva de compostos bioactivos, nomeadamente polifenóis, que fornecem actividade antioxidante. No presente trabalho pretendeu-se desenvolver e avaliar formulações contendo chá verde ou chá preto e contendo os filtros solares avobenzona (filtro solar UVA) e octilmetoxinamato (filtro solar UVB), no sentido de as tornar fotoestáveis e eficazes, proporcionando amplo espectro de fotoprotecção. Estas formulações foram desenvolvidas com substituição total da fase externa da emulsão óleo/água $(\mathrm{O} / \mathrm{A})$ por estes chás. Os resultados obtidos permitiram concluir que ambos os chás apresentaram capacidade fotostabilizadora, com especial foco para o chá verde nas condições de armazenamento à temperatura ambiente e a $5^{\circ} \mathrm{C}$, e para o chá preto nas amostras armazenadas a $40{ }^{\circ} \mathrm{C}$.

Palavras-chave: Chá verde, chá preto, formulações fotoprotetoras, capacidade fotoestabilizadora, octil metoxicinamato, avobenzona 


\section{Introduction}

Ultraviolet (UV) radiation causes adverse effects on the skin, such as cancer, immune system suppression, photoaging ${ }^{[1]}$ and exacerbation of photosensitive diseases ${ }^{[2]}$, among others. Sunscreens are increasingly used and recommended for prevention and protection from sun exposure ${ }^{[1]}$ because they constitute the first line of protection against the adverse effects of UV radiation ${ }^{[3]}$. Although the more recently available sunscreens have greater protection capacity, the absorption spectra of some sunscreens change after irradiation with UV radiation ${ }^{[4]}$. The reactive intermediates of photo-unstable sunscreens come in direct contact with the skin, where they can act as photo-oxidants, promoting phototoxicity or photoallergic contact dermatitis ${ }^{[4]}$. On the other hand, interaction with photodegradation products of sunscreens or skin components such as sebum may lead to the formation of molecules with unknown toxicological properties ${ }^{[4]}$. Therefore, it is of utmost importance to develop photostable sunscreens, including chemical filters which must absorb UV radiation and physical filters which should reflect and scatter radiation ${ }^{[5]}$. Usually, at least two filters are used in a sunscreen, in order to favour higher SPF values (sun protection factor), one for the UVB (290-320 nm) and one for the UVA (320$400 \mathrm{~nm}$ ) region.

In this work, Gorreana ${ }^{\circledR}$ tea, a Portuguese tea produced in the Azores since 1883, was used. The green tea is produced by steaming the leaves of Camellia sinensis. It has a light taste and does not contain as much caffeine as black tea ${ }^{[6]}$. Green tea is rich in catechins, and thus has attracted much attention, as these have relatively high antioxidant activity and are abundant in the human diet. Several reports demonstrated that topical application or oral intake of green tea polyphenols prevent the development of carcinomas ${ }^{[1]}$. The major green tea catechins are (-)-epigallocatechin-3-gallate (EGCG; 9-13 \%), (-)-epigallocatechin (EGC; 3-6 \%), (-)-epicatechin-3-gallate (ECG ; 3-6 \%), (-)-epicatechin $(\mathrm{EC} ; 1-3 \%)$ and $(+)$-catechin $(\mathrm{C} \text {, less than } 1 \%)^{[1]}$. Several catechins found in this tea have demonstrated antioxidant activity ${ }^{[5,7]}$ and skin photoprotection ${ }^{[8]}$. A previous study showed that the galoil catechins, especially EGCG, provide effective protection against oxidative stress caused by UVB radiation ${ }^{[9]}$. EGCG is also considered a natural antioxidant and a slimming agent. It contains folic acid, vitamin C, K, B1 and B2 and is used against aging. Black tea is obtained by oxidation of leaves of Camellia sinensis, yielding thereby a reddish and dark colour. It has a strong taste and contains caffeine ${ }^{[6]}$. Black tea has less antioxidant activity than

\section{Introdução}

A radiação ultravioleta (UV) provoca efeitos nefastos na pele, como o cancro, supressão do sistema imunitário, fotoenvelhecimento ${ }^{[1]} \mathrm{e}$ exacerbação de doenças fotossensíveis ${ }^{[2]}$, entre outros.

Os protectores solares são cada vez mais utilizados e recomendados como medida de prevenção e de protecção da exposição solar ${ }^{[1]}$ por constituírem primeira linha de protecção contra os efeitos adversos da radiação UV [3]. Embora os protectores solares produzidos mais recentemente apresentem maior capacidade de protecção, os espectros de absorção de alguns filtros solares alteram-se após irradiação com radiação UV ${ }^{[4]}$. Os intermediários reactivos de filtros fotoinstáveis entram em contacto directo com a pele, onde se podem comportar como foto-oxidantes, promover fototoxicidade ou dermatite de contacto fotoalérgica ${ }^{[4]}$. Por outro lado, a interação entre produtos da fotodegradação com excipientes dos filtros solares ou com os componentes da pele, como o sebo, pode levar à formação de moléculas com propriedades toxicológicas desconhecidas ${ }^{[4]}$. Surge então a necessidade de desenvolver protectores solares fotoestáveis, isto é, no caso dos filtros químicos devem absorver radiação UV e no caso dos filtros físicos, devem reflectir e dispersar a radiação ${ }^{[5]}$. Na maioria dos protectores solares, são utilizados pelo menos dois filtros para favorecer maiores valores de FPS (fator de proteção solar), preferencialmente, com abrangência na região do UVB (290-320 nm) e UVA (320-400 nm). Neste trabalho usou-se chá da Gorreana ${ }^{\circledR}$, um chá português produzido nos Açores desde 1883. O chá verde é produzido por meio da vaporização das folhas de Camellia sinensis. Possui sabor leve e não possui tanta cafeína como o chá preto ${ }^{[6]}$. O chá verde é rico em catequinas, pelo que tem atraído muita atenção, pois estas têm actividade antioxidante relativamente elevada e são abundantes na dieta humana. Foi demonstrado que a aplicação tópica ou a ingestão oral de polifenóis do chá verde impede o desenvolvimento de carcinomas ${ }^{[1]}$. As principais catequinas do chá verde são a (-)-epigalocatequina-3-galato (EGCG; 9-13\%), (-)-epigalocatequina (EGC; 3-6 \%), (-)-epicatequina-3-galato (ECG; 3-6\%), (-)-epicatequina $(\mathrm{EC} ; 1-3 \%)$, e (+)-catequina $(\mathrm{C}, \text { menos de } 1 \%)^{[1]}$. Várias catequinas encontradas neste chá têm demonstrado atividade antioxidante ${ }^{[5,7]}$ e fotoprotecção cutânea ${ }^{[8]}$. Um estudo anterior evidenciou que as catequinas galoil, especialmente EGCG, conferem protecção eficaz contra o stress oxidativo causado pelas radiações UVB [9]. O chá verde é também considerado um antioxidante natural, adelgaçante, possui ácido fólico, vitamina $\mathrm{C}$, $\mathrm{K}, \mathrm{B} 1$ e B2 e é utilizado contra o envelhecimento. O chá preto é obtido por meio da oxidação substancial das folhas da Camellia sinensis, originando, assim, uma cor avermelhada, escura. Possui um sabor forte e contém cafeína ${ }^{[6]}$. O chá preto apresenta menor actividade antioxidante relativamente ao chá verde, no entanto é rico 
green tea, but is richer in tannins. Black tea has been less studied than green tea, and therefore there is less information available about its contribution to photoprotection. Antioxidants are widely used in cosmetics and as a complement to the photoprotection provided by UV filters.

Reactive oxygen species (ROS) are formed by UV radiation, resulting in oxidative damage to cellular components such as mitochondria and nuclear DNA, which in turn accelerate aging and can contribute to cancer ${ }^{[1]}$. Antioxidants play an important role in protecting skin against damage induced by ROS. Several antioxidants, such as ascorbic acid, $\alpha$-tocopherol, and others were reported to inhibit skin carcinogenesis induced by UV radiation ${ }^{[1]}$. Thus, this work aims at the development and physic-chemical and functional characterization (in vitro efficacy) of multifunctional bioactive photoprotective containing green and black tea.

\section{Materials and methods}

\section{Materials}

Aristoflex ${ }^{\circledR}$ AVC (Ammonium Acryloyldimethyltaurate/VP Copolymer) (Clariant, Germany); Butylated hydroxytoluene (BHT) (Mapric, Brazil); Isopropyl Myristate (Pharma Special, Brazil); Ethylhexyl Methoxynnamate (Mapric, Germany); Avobenzone (Butyl Methoxydibenzoylmethane) (Pharma Special, India); Disodium EDTA (Fagron, Spain), Polyethylene glycol 4000 (PEG 400) (Dow, Netherlands); Propylene glycol (Mapric, Brazil); Green Tea and Black Tea (Gorreana ${ }^{\circledR}$, Azores). All materials were of pharmaceutical grade and were used without further purification.

\section{Methods}

\section{Tea preparation}

Distilled water was heated to $90{ }^{\circ} \mathrm{C}$. The amount of water used was dependent on the weight of the tea bag, in a proportion of two grams of tea per $250 \mathrm{~mL}$ of water. After the water reached the desired temperature, the tea bag was added, and after 5 minutes, it was removed and the tea solution was stirred 10 times in the same direction. The preparation was filtered immediately and allowed to cool.

\section{Preparation of emulsions}

The composition of the chosen formulations is shown in Table 1. The preparation procedure was started by em taninos. Este chá não é alvo de tantos estudos como o verde, existindo menos informação disponível sobre o seu contributo para a fotoprotecção. Os antioxidantes são amplamente utilizados em cosméticos e como complemento da fotoproteção oferecida pelos filtros UV. As espécies reativas de oxigénio (ROS) são formadas pela radiação UV, resultando em danos oxidativos nos componentes celulares, tais como mitocôndrias e DNA nuclear, que por sua vez acelera o envelhecimento e pode contribuir para o cancro ${ }^{[1]}$. Os antioxidantes desempenham um importante papel, pois protegem a pele contra as lesões induzidas pelas ROS. Numerosos antioxidantes, tais como o ácido ascórbico, $\alpha$-tocoferol e outros foram relatados como inibidores da carcinogénese da pele, induzida por UV ${ }^{[1]}$. O presente trabalho tem assim, como objectivo, o desenvolvimento, preparação e caracterização físico-química e funcional (eficácia in vitro) de fotoprotectores bioactivos multifuncionais contendo o chá verde ou chá preto.

\section{Material e métodos}

\section{Materiais}

Aristoflex ${ }^{\circledR}$ AVC (co-polímero de Acriloildimetiltaurato de amonio) (Clariant, Alemanha); Hidroxitouleno butilado (BHT) (Mapric, Brasil); Miristato de isopropilo (Pharma Special, Brasil); Metoxicinamato de etilhexilo (Mapric, Alemanha); Avobenzona (Metoxidibenzoilmetano de butilo) (Pharma Special, India); ácido etilenodiamino tetra-acético (EDTA) (Fagron, Espanha), Polietileno glicol 4000 (PEG 400) (Dow, Holanda); Propileno glicol (Mapric, Brasil); chá verde e chá preto (Gorreana ${ }^{\circledR}$,Açores). Todos os materiais utilizados eram de grau farmacêutico e foram usados sem qualquer purificação adicional.

\section{Métodos}

Preparação dos chás

Aqueceu-se água destilada a $90{ }^{\circ} \mathrm{C}$, sendo que a quantidade de água utilizada é dependente do peso da saqueta do chá, numa porporção de duas gramas de chá por 250 $\mathrm{mL}$ de água. Depois de a água se encontrar à temperatura pretendida, adicionou-se a saqueta de chá e ao fim de 5 minutos retirou-se a mesma. De seguida, agitou-se manualmente 10 vezes no mesmo sentido. Filtrou-se de imediato e deixou-se arrefecer.

\section{Preparação das emulsões}

A composição das emulsões escolhidas está representada na Tabela 1. Quanto ao procedimento, pesaram-se 
separately weighing the compounds constituting the oily and aqueous phases

[water (placebo), or black tea, or green tea], except Aristoflex ${ }^{\circledR}$, which was added later in the aqueous phase after all compounds were weighed. Then the compounds were heated to $60{ }^{\circ} \mathrm{C}$ on a hot plate and oil phase was added to the aqueous phase with mechanical stirring via a "KIKA Labortechnik mixer", maximum power, for about 5 minutes. os compostos da fase oleosa e separadamente os componentes da fase aquosa [água (placebo), ou chá preto, ou chá verde], à excepção do Aristoflex ${ }^{\circledR}$ que foi adicionado à fase aquosa sob a forma depois de todos os compostos estarem pesados. De seguida aqueceram-se os compostos até aos $60^{\circ} \mathrm{C}$, numa placa de aquecimento, e adicionou-se a fase oleosa à aquosa sob agitação máxima de um misturador mecânico de marca KIKA Labortechnik, durante cerca de $5 \mathrm{~min}$.

Table 1 / Tabela 1 - O/W Emulsion either with water or green tea or black tea as external phase

Emulsão O/A com água ou chá verde ou chá preto como fase externa

\begin{tabular}{lc}
\hline Compostos/ & $\%(\mathbf{m} / \mathbf{m})$ \\
Compounds & $\%(\mathbf{w} / \mathbf{w})$ \\
\hline Fase oleosa/Oily Phase & 0.1 \\
BHT & 2 \\
Isopropyl Myristrate & 5 \\
Avobenzone & 10 \\
Octyl Methoxynnamate & \\
\hline Fase aquosa/Aqueous Phase & 2 \\
Aristoflex & 0.1 \\
EDTA & 5 \\
Polyethylene glycol 4000 & 5 \\
Propylene glycol & 70.8 \\
Water or Green Tea or Black Tea & \\
\hline
\end{tabular}

Preliminary stability studies

\section{Centrifuge Test}

The formulations were subjected to a centrifugation test. Approximately $5 \mathrm{~g}$ of each formulation was weighed in centrifuge tubes in duplicate. The study was carried out at room temperature, rotation speed $3000 \mathrm{rpm}(210 \mathrm{~g})$ for 30 minutes.

\section{Heat stress test}

About $5 \mathrm{~g}$ of each formulation were weighed in centrifuge tubes in duplicate. The test was initiated at $40{ }^{\circ} \mathrm{C}$ and ended at $80{ }^{\circ} \mathrm{C}$ with the temperature elevated by $10{ }^{\circ} \mathrm{C}$ every 30 minutes. After the final incubation, the
Estudos de estabilidade preliminar

Teste de centrifugação

As emulsões foram sujeitas a um teste de centrifugação. Pesaram-se cerca de $5 \mathrm{~g}$ de cada formulação em tubos de centrífuga, em duplicado. $O$ estudo foi realizado à temperatura ambiente, a velocidade de rotação de $3000 \mathrm{rpm}(210 \mathrm{~g})$ e durante $30 \mathrm{~min}$.

\section{Teste de stress térmico}

Pesaram-se cerca de $5 \mathrm{~g}$ de formulação para tubos de ensaio em duplicado. O ensaio, em banho termostatizado, iniciou-se aos $40^{\circ} \mathrm{C}$ e terminou aos $80^{\circ} \mathrm{C}$, com um incremento de temperatura de $10^{\circ} \mathrm{C}$ a cada $30 \mathrm{~min} .{ }^{[10]}$. 
replicas were taken from this condition and evaluated [10].

\section{Storage stability}

Emulsions with and without green or black tea were stored under different temperatures (room temperature $25.0 \pm 2.0^{\circ} \mathrm{C}$ under indirect light, refrigerator at $5.0^{\circ} \mathrm{C} \pm$ $0.5^{\circ} \mathrm{C}$, freezer at $5.0{ }^{\circ} \mathrm{C} \pm 0.5^{\circ} \mathrm{C}$; oven at $40.0 \pm 0.5^{\circ} \mathrm{C}$ ) for 14 days. At time $t_{0,} t_{6,} t_{7}, t_{12}$ and $t_{14}$ the samples were analysed regarding $\mathrm{pH}$, viscosity and organoleptic properties.

\section{In vitro Photoprotection efficacy}

Photoprotection efficacy of emulsions (with green or black tea or placebo) were analysed as follows. A diffuse reflectance spectrophotometer with integrating sphere (Labsphere ${ }^{\circledR}$ UV2000S Ultraviolet Transmittance Analyzer) was used to evaluate the in vitro efficacy against the UVA and UVB radiations of photoprotective formulations developed. Samples $\left(1.3 \mathrm{mg} / \mathrm{cm}^{2}\right)$ were applied in a circular motion evenly on the substrate (quartz with $3 \mathrm{M}^{\mathrm{TM}}$ transpore ${ }^{\mathrm{TM}}$ tape) as a thin film on the surface of the plate. Spectrophotometric data of the samples applied on the plate over the substrate, including the wavelength range $(\lambda)$ of 290 and $400 \mathrm{~nm}$ and recording every $1.0 \mathrm{~nm}$, determined SPF values and the length of critical wavelength $(\lambda c)$ using the UV-2000S ${ }^{\circledR}$ program. Each sample was analysed in triplicate, with at least five recordings of transmittance ${ }^{[11]}$. After completion of the photoprotective activity determination in vitro, the quartz plates containing the samples were irradiated for 1 hour. The irradiance was maintained at $580.08 \mathrm{~W} / \mathrm{m}^{2}$ (300-800 nm), which corresponds to the UV irradiance of $55 \mathrm{~W} / \mathrm{m}^{2}\left(\right.$ dose $\left.=198 \mathrm{~kJ} / \mathrm{m}^{2}\right)$. The SPF parameters and critical wavelength post-irradiation were analysed and compared with pre-irradiation values. Each sample was analysed in triplicate, and at least in five measurements of transmittance were collected ${ }^{[12]}$. Plates without formulation were used as the control.

\section{Results and Discussion}

Tea is widely known as a nutritional source of bioactive compounds, namely polyphenols, with antioxidant activity. Thus, tea could be helpful in the protection of cells and tissues against reactive oxygen and nitrogen species and, consequently, prevent a wide variety of diseases. In this work several sunscreen formulations were developed with a total replacement of the external phase of the $\mathrm{O} / \mathrm{W}$ emulsion by infusions of green or black tea (Figure 1a-c).
Estabilidade durante o armazenamento

Emulsões com e sem chá verde ou preto foram armazenadas sob diferentes temperaturas (temperatura ambiente de $25,0 \pm 2,0^{\circ} \mathrm{C}$ sob luz indireta, frigorífico a 5,0 ${ }^{\circ} \mathrm{C} \pm 0,5^{\circ} \mathrm{C}$, e estufa a $40,0 \pm 0,5^{\circ} \mathrm{C}$ ) durante 14 dias. No tempo $t_{0}, t_{6}, t_{7}, t_{12}$ e $t_{14}$, as amostras foram analisadas quanto ao $\mathrm{pH}$, viscosidade e propriedades organolépticas.

\section{Eficácia fotoprotetora in vitro e fotoestabilidade}

A eficácia fotoprotetora das emulsões (contendo chá verde, ou cha preto, ou o placebo) foram analisadas da seguinte forma. Um espectrofotómetro de refletância difusa com esfera de integração (Labsphere ${ }^{\circledR}$ UV2000S Ultraviolet Transmittance Analyzer) foi utilizado para a avaliação da eficácia in vitro frente à proteção UVA e UVB das formulações fotoprotetoras desenvolvidas. Amostras $\left(1,3 \mathrm{mg} / \mathrm{cm}^{2}\right)$ foram aplicadas uniformemente sobre o substrato (quartzo com fita transpore ${ }^{\mathrm{TM}} 3 \mathrm{M}^{\mathrm{TM}}$ ), na forma de filme fino em movimentos circulares sobre a superfície da placa. Os dados espectrofotométricos das amostras aplicadas na placa sobre o substrato, compreendendo o intervalo de comprimento de onda $(\lambda)$ entre 290 e $400 \mathrm{~nm}$ e registros a cada $1,0 \mathrm{~nm}$, determinaram os valores do FPS e o comprimento de onda crítico $(\lambda c)$ por meio do programa UV-2000S ${ }^{\circledR}$. Cada amostra foi analisada em triplicado e no mínimo, cinco registros de transmitância foram obtidos ${ }^{[1]}$. Após realização do ensaio da atividade fotoprotetora in vitro, as placas de quartzo contendo as amostras foram irradiadas por 1 hora. A irradiância foi mantida a 580,08 W/m² $(300-800$ $\mathrm{nm})$, o que corresponde a irradiância no UV de $55 \mathrm{~W} /$ $\mathrm{m}^{2}\left(\right.$ Dose $\left.=198 \mathrm{~kJ} / \mathrm{m}^{2}\right)$. Os parâmetros FPS e comprimento de onda crítico pós-irradiação foram analisados e comparados com os valores obtidos pré-irradiação. Novamente, cada amostra foi analisada em triplicado e, no mínimo, cinco registros de transmitância foram obtidos ${ }^{[12]}$ respectively butyl methoxydibenzoylmethane (BMDBM. Foi necessária a utilização de placas sem formulação como placebo.

\section{Resultados e Discussão}

O chá é vastamente reconhecido como fonte nutricional de compostos bioactivos, nomeadamente de polifenóis, que apresentam actividade antioxidante. Pelo exposto, os chás poderão auxiliar na proteção de células e tecidos contra as espécies reactivas de oxigénio e de azoto e, consequentemente prevenir uma variedade de doenças. Assim, neste trabalho, as formulações dermocosméticas fotoprotetoras foram desenvolvidas com substituição total da fase externa da emulsão O/A pelo produto da infusão do chá verde ou do chá preto (Figura 1a-c). 

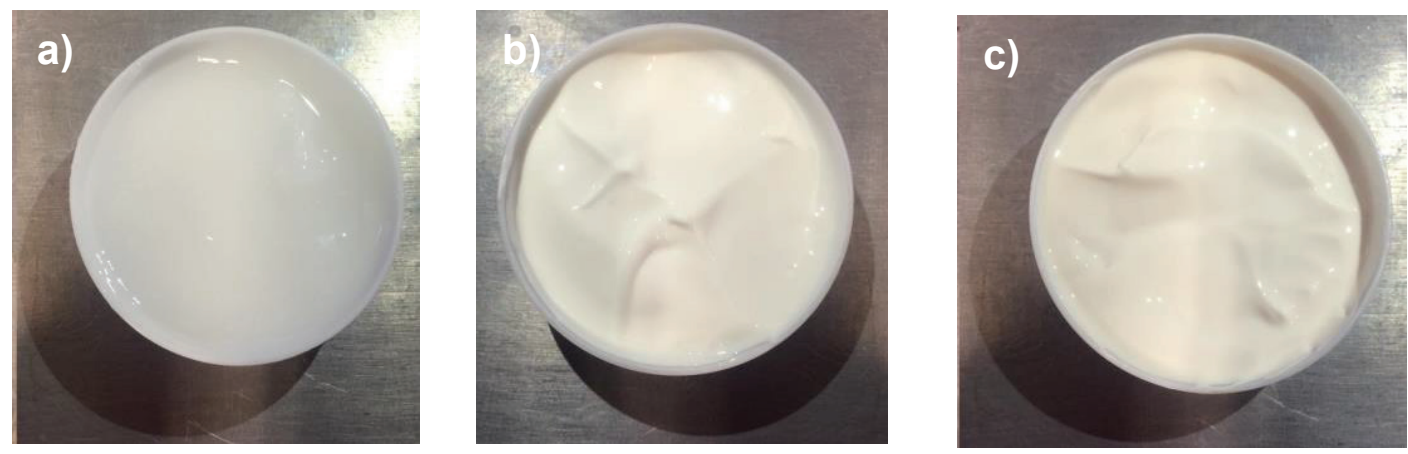

Figure 1/ Figura 1 - a) Placebo emulsion; b) Green tea emulsion; c) Black tea emulsion

a) Emulsão Placebo; b) Emulsão com chá verde; c) Emulsão com chá preto.

The study of the stability of cosmetic products provides information that indicates the degree of relative stability of a product under different conditions to which it can be subjected, from its production and until the end of the expiration date. This stability is relative, since it varies with time and factors that speed or retard the changes in the product parameters ${ }^{[10]}$. The stability assay is considered a predictive procedure, based on data obtained from products stored in conditions that aim to accelerate changes that may occur under marketing conditions. As in every other predictive procedure, its results are not absolute, but are likely to be successful $[13,14]$. The systems developed in this research were challenged by assays that promote accelerated product ageing, using stress conditions of temperature, in a short time frame.

All formulations showed to be stable after the preliminary stability studies, since no signs of flocculation and/ or phase separation were observed. The appearance was similar to the ones before storage_(Figure 1a-c). During storage stability no changes were observed in terms of $\mathrm{pH}$, viscosity and organoleptic properties from $t_{0} t_{6}, t_{7}$, $t_{12}$ and $t_{14}$ (data not shown).

As estimated through the Sun Protection Factor (SPF), sunscreens containing black or green tea developed an efficacy that was different from the one with water as external phase (Figure 2). It was noted that the replacement of purified water with green tea improved the efficacy of the system. After irradiation in a photostability chamber, the samples of placebo and the samples containing black tea showed a reduction in the SPF of 47 and $52 \%$, respectively, and a reduction of $18 \%$ in the sample with green tea (Figure 2). Regarding the critical wavelength, regardless of the differences within formulations, the response profile observed was similar between, resulting in values between 375 and $377 \mathrm{~nm}$ (before irradiation). The difference between the critical wavelength observed before and after irradiation
O estudo da estabilidade de produtos cosméticos fornece informações que indicam o grau de estabilidade relativa de um produto nas variadas condições a que possa estar sujeito desde o seu fabrico até ao término da validade. Essa estabilidade é relativa, pois varia com o tempo e depende de fatores que aceleram ou retardam alterações nos parâmetros do produto ${ }^{[10]}$. O teste de estabilidade é considerado um procedimento preditivo, baseado em dados obtidos de produtos armazenados em condições que visam a acelerar alterações passíveis de ocorrer nas condições de mercado. Como em todo procedimento preditivo, os resultados não são absolutos, mas têm enorme probabilidade de sucesso ${ }^{[13,14]}$. Os sistemas desenvolvidos neste trabalho de pesquisa foram desafiados por meio de ensaios que promovem o envelhecimento acelerado dos mesmos, tais como condições de stress de temperatura, luz e humidade, num curto período de tempo. Todas as formulações mostraram ser estáveis após os estudos preliminares de estabilidade, uma vez que não há sinais de floculação e/ou de separação de fases. $\mathrm{O}$ aspecto foi semelhante ao das amostras antes do armazenamento (Figura 1a-c). Durante o armazenamento não foram observadas alterações em termos de $\mathrm{pH}$, viscosidade e das propriedades organolépticas de $t_{0}, t_{6}, t_{7}, t_{12}$ e $t_{14}$ (dados não mostrados). Como estimado por meio do Fator de Proteção Solar (FPS), os protetores solares contendo chá preto ou verde desenvolveram uma eficácia que era diferente da formulação que continha a água como fase externa (Figura 2). Notou-se que a substituição de água purificada com o chá verde melhorou a eficácia do sistema. Após a irradiação, numa câmara de fotoestabilidade, as amostras de placebo e as amostras contendo o chá preto mostraram uma redução no SPF de 47 e 52 \%, respectivamente, enquanto que a amostra contendo chá verde apresentou uma redução de $18 \%$ (Figura 2). Quanto ao valor do comprimento de onda crítico, independente das distinções entre as formulações, o perfil de resposta foi aparentemente similar entre as amostras, que resultou em valores de 375 a $377 \mathrm{~nm}$ (antes da irradiação). A 


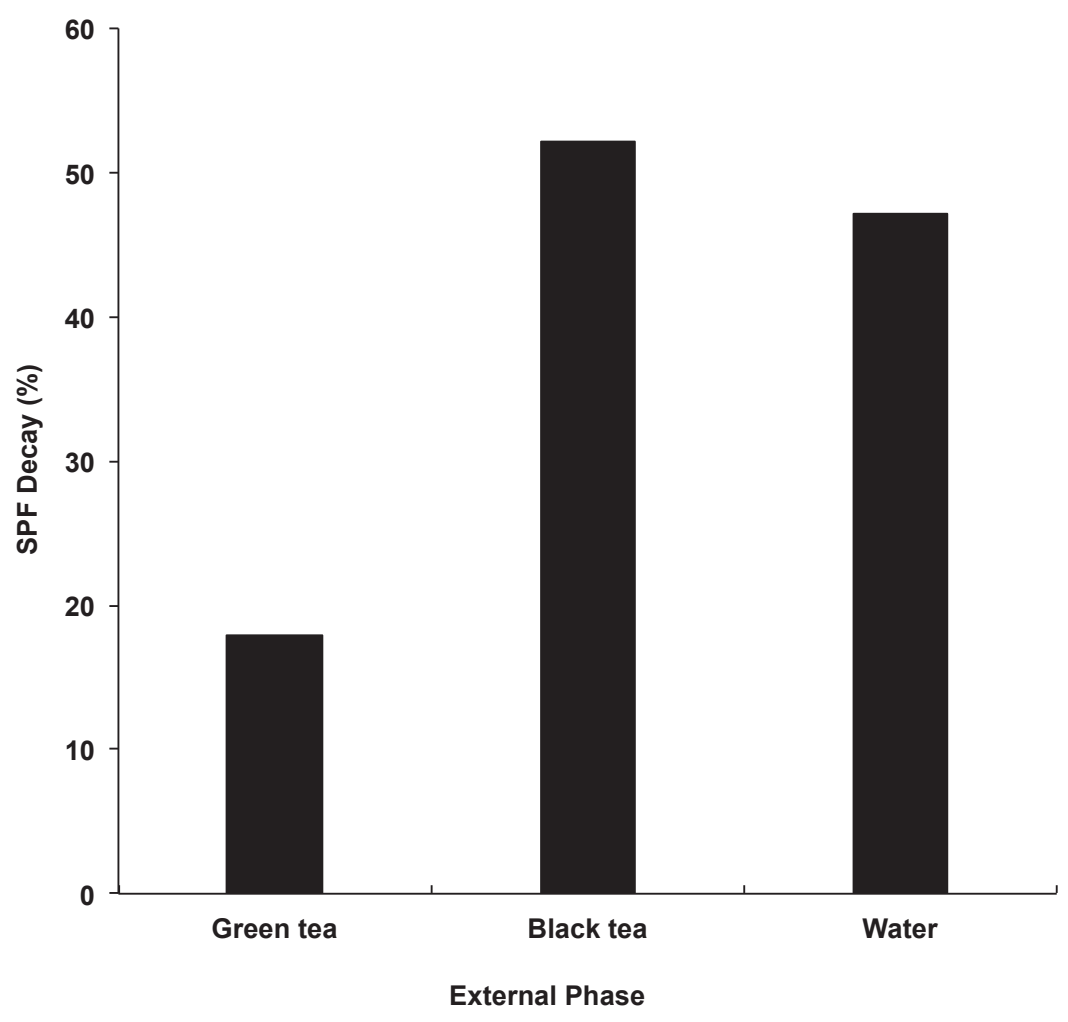

Figure 2/ Figura 2 - SPF decay (\%) of emulsions with green tea or black tea or water as external phase, after preparation.

Decaimento FPS (\%) de emulsões contendo chá verde ou chá preto ou água como fase externa, após a preparação.

was lower for the samples containing green or black tea (with a decay of $0.27 \%$ for both), whereas the placebo had a higher decay of $0.53 \%$ (Table 2)

For the samples containing green tea or black tea, the sunscreen systems were analysed in regard to changes in the functional photostability by storing the samples at different temperatures $\left(5^{\circ} \mathrm{C}\right.$, room temperature and $40{ }^{\circ} \mathrm{C}$ ) at 14 days. The green tea appeared to provide photostability of greater magnitude at low and room temperatures, showing a reduction of the estimated efficacy of $20.5 \%$ and $8.7 \%$, respectively. The black tea provided SPF decay values above $11 \%$ for the sample at room temperature and $36.5 \%$ for the sample at $5{ }^{\circ} \mathrm{C}$ (Figure 3).

Despite the improved performance of the green tea as a potential photostabilizing agent, unexpectedly, the black tea developed favourable properties for the conservation of the SPF of the sunscreen systems when the samples were stored at $40{ }^{\circ} \mathrm{C}$, with a reduction of the SPF by $0.7 \%$ (under the same conditions, the green tea decreased by approximately $18 \%$ ). According to our results, the SPF reduction may be attributed to the octyl methoxycinnamate molecule photoisomerization and/or the displacement of keto/enol equilibrium of the avobenzone that would compromise the absorption intensity of the UV radiation. It is noteworthy to diferença entre o valor do comprimento de onda crítico observado antes e após a irradiação foi inferior para as amostras contendo o chá verde ou o chá preto (decaimento de $0,27 \%$ para ambas) e, o placebo, apresentou um decaimento superior, de $0,53 \%$ (Tabela 2). Para as amostras contendo o chá verde ou chá preto, os sistemas de protecção solar foram analisados em relação às mudanças na fotoestabilidade funcional através do armazenando das amostras a diferentes temperaturas $\left(5^{\circ} \mathrm{C}\right.$, temperatura ambiente e $40^{\circ} \mathrm{C}$ ) ao fim de 14 dias. O chá verde pareceu fornecer fotoestabilidade de maior magnitude a temperaturas baixas e à temperatura ambiente, mostrando uma redução da eficácia estimada de 20,5\% e $8,7 \%$, respectivamente. O chá preto proporcionou valores de decaimento FPS acima de $11 \%$ para a amostra à temperatura ambiente, e de $36,5 \%$ para a amostra a $5{ }^{\circ} \mathrm{C}$ (Figura 3 ).

Apesar do desempenho melhorado do chá verde como potencial agente fotoestabilizador, inesperadamente, o chá preto desenvolveu propriedades favoráveis para a conservação do FPS dos sistemas fotoprotetores nas condições de armazenamento das amostras a $40{ }^{\circ} \mathrm{C}$, tendo redução do FPS de 0,7 \% (o chá verde, nas mesmas condições e parâmetro de análise, possuiu diminuição de $18 \%$, aproximadamente). De acordo com os nossos resultados, a redução do FPS pode ser atribuído à fotoisomerização da molécula do metoxicinamato de 
mention that avobenzone exists predominantly in its enol form, which is responsible for the UVA absorption ${ }^{[15]}$. It has also been reported that the light-induced degradation mechanism of octyl methoxycinnamate and avobenzone proceeds through the free radicals and singlet oxygen formation, and the use of antioxidants that scavenge these reactive species could reduce signs of photoinstability involving the UV filters previously mentioned ${ }^{[16]}$. Thus, in this research work, our results could be attributable to the polyphenols contained in the tea samples, but more studies must be conducted to fully understand these systems. octila e / ou ao deslocamento do equilíbrio ceto / enol da avobenzona que comprometeria a intensidade de absorção da radiação UV. Ressaltamos que avobenzona existe predominantemente na sua forma de enólica, que é responsável pela absorção no UVA ${ }^{[15]}$. É também sabido que o mecanismo de degradação induzido pela luz do metoxicinamato de octilo e avobenzona prossegue por meio da formação radicais livres e oxigênio singlet e o uso de antioxidantes pode reduzir os sinais de fotoinstabilidade envolvendo os filtros UV mencionados anteriormente ${ }^{[16]}$. Assim, neste trabalho de pesquisa, os polifenóis contidos nas amostras de chá poderiam ser responsáveis pelos promissores resultados obtidos, embora seja necessário efectuar mais estudos para compreender estes sistemas na plenitude.

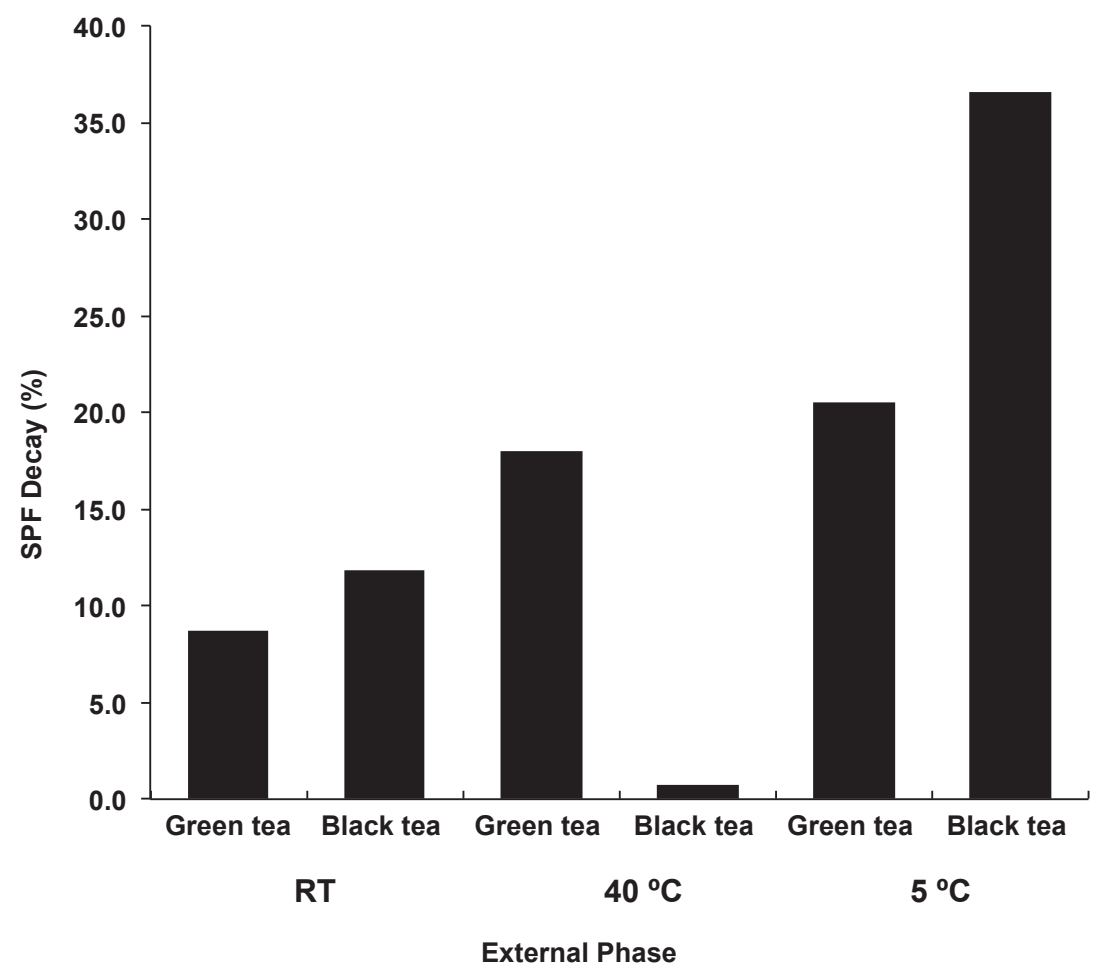

Figure 3/ Figura 3 - SPF decay (\%) of emulsions with green tea or black tea after storage during 14 days at room temperature (RT), $40{ }^{\circ} \mathrm{C}$ and at $5{ }^{\circ} \mathrm{C}$.

Decaimento FPS (\%) de emulsões contendo chá verde ou chá preto, após armazenamento à temperatura ambiente, a $40^{\circ} \mathrm{C}$ e a $5{ }^{\circ} \mathrm{C}$. 
Table 2 / Tabela 2 - Photoprotective efficacy of emulsions with water or green tea or black tea as external phase

Eficácia fotoprotetora de emulsões contendo água, ou chá verde, ou chá preto como fase externa

\begin{tabular}{lcccccc}
\hline $\begin{array}{l}\text { External phase of } \\
\text { emulsion }\end{array}$ & $\mathrm{SPF}_{\mathrm{i}}$ & $\mathrm{SPF}_{\mathrm{f}}$ & $\begin{array}{c}\mathrm{SPF} \\
\text { decay } \\
(\%)\end{array}$ & $\begin{array}{c}\text { Critical } \lambda_{\mathrm{i}} \\
(\mathrm{nm})\end{array}$ & $\begin{array}{c}\text { Critical } \lambda_{\mathrm{f}} \\
(\mathrm{nm})\end{array}$ & $\begin{array}{c}\text { Decay } \\
(\%)\end{array}$ \\
\hline Water & 157.7 & 82.3 & 47.2 & 376.8 & 374.7 & 0.53 \\
Green tea & 133.7 & 111.7 & 189.0 & 375.3 & 374.3 & 0.27 \\
Black tea & 132.5 & 55.5 & 52.2 & 375.0 & 374.0 & 0.27 \\
\hline
\end{tabular}

\section{Conclusion}

In conclusion, the results of this preliminary study allow us to conclude that both teas presented photostabilizing ability, with special focus for green tea in storage conditions at room temperature and at $5{ }^{\circ} \mathrm{C}$, and for black tea in the samples stored at $40{ }^{\circ} \mathrm{C}$, which indicated that the complete replacement of the external phase of the $\mathrm{O} / \mathrm{W}$ emulsion in tea infusions may be a favourable alternative for promoting photostabilization of sunscreens. Consequently, by the photostabilization observed, this study is an excellent indicator that the development of new photoprotective formulations containing teas, and possibly other functional foods, is highly promising in the field of photoprotection.

\section{Acknowledgements}

FAPESP and PADDIC for the financial support.

\section{Conflict of Interests}

The authors declare that there are no financial and/or personal relationships that could be viewed as presenting a potential conflict of interests.

\section{Conclusão}

Em suma, os resultados obtidos neste estudo permitem concluir que ambos os chás apresentaram capacidade fotoestabilizadora, com especial foco para o chá verde nas condições de armazenamento à temperatura ambiente e a $5^{\circ} \mathrm{C}$, e para o chá preto nas amostras armazenadas a $40{ }^{\circ} \mathrm{C}$, o que indicou que a substituição total da fase externa da emulsão $\mathrm{O} / \mathrm{A}$ por infusões de chás poderá ser uma alternativa favorável para o alcance da fotoestabilização de protetores. Consequentemente, este estudo é um excelente indicador de que o desenvolvimento de novas formulações fotoprotectoras contendo chás, e possivelmente outros alimentos funcionais, é extremamente promissora na área da fotoprotecção, por mecanismos de fotoestabilização.

\section{Agradecimentos}

FAPESP e PADDIC, pelo apoio financeiro.

\section{Conflito de Interesses}

Os autores declaram a inexistência de qualquer tipo de relação financeira ou pessoal que possa representar um potencial conflito de interesses. 


\section{References/ Referências}

[1] Chieh-Chen Huang, et al. (-)-Epicatechin3-gallate, a Green Tea Polyphenol Is a Potent Agent Against UVB-induced Damage in HaCaT Keratinocytes. Molecules 2007; 12:1845- 58 .

[2] Baron ED, Kirkland EB, Domingo, Santo D. Advances in Photoprotection. Dermatology nursing 2008; 20, 4: 265-72.

[3] Dondi D, Albini A, Serpone N. Interactions between different solar UVB/UVA filters contained in commercial suncreams and consequent loss of UV protection. Photochemical \& Photobiological Science 2006; 5: 835-43.

[4] Gaspar LR, Maia Campos PMBG. Evaluation of the photostability of different UV filter combinations in a sunscreen, International Journal of pharmaceutics 2005; 306:123-28.

[5] Katiyar, SK, Elmets CA. Green tea polyphenolic antioxidants and skin photoprotection (Review). Int. J. Oncol. 2001; 18: 1307-13.

[6] Chá Gorreana - Produtos, in: URL: "http:// www.gorreana.org/index.php/pt/produtos
[7] Katiyar SK, Afaq, F, Perez A, Mukhtar, H. Green tea polyphenol (-)-epigallocatechin3 -gallate treatment of human skin inhibits ultraviolet radiation-induced oxidative stress. Carcinogenesis 2001; 22: 287-94.

[8] Elmets CA, Singh D, Tubesing K, Matsui M, Katiyar S, Mukhtar H. Cutaneous photoprotection from ultraviolet injury by green tea polyphenols. J. Am. Acad. Dermatol. 2001; 44: 425-432.

[9] Katiyar SK, Afaq F, Azizuddin K, Mukhtar H. Inhibition of UVB-induced oxidativestressmediated phosphorylation of mitogen-activated protein kinase signaling pathways in cultured human epidermal keratinocytes by green tea polyphenol (-)-epigallocatechin3-gallate. Toxicol. Appl. Pharmacol. 2001; 176: 110-7.

[10] Baby AR et al. Estabilidade e estudo de penetração cutânea in vitro da rutina veiculada em uma emulsão cosmética através de um modelo de biomembrana alternativo. Rev. Bras. Cienc. Farm. 2008; 44(2): 233-48.
[11] Velasco MVR, Sarruf FD, Sakgado-Santos IMN, Haroutiounian-Filho CA, Kaneko TM, Baby AR, Broad spectrum bioactive sunscreens. Intern. J. Pharm. 2008; 363, 50-57.

[12] Scalia S, Mezzena M. Photostabilization effect of quercetin on the UV filter combination, butyl methoxydibenzoylmethane-octyl methoxycinnamate. Photochem Photobiol 2010; 86(2):273-8.

[13] Brasil. Ministério da Saúde. Agência Nacional de Vigilância Sanitária. Guia de estabilidade de produtos cosméticos. Brasília, 2004. p.45.

[14] Velasco MVR, Maciel CPM, Sarruf FD, Pinto, CASO, Consiglieri VO, Kaneko TM, Baby, AR. Desenvolvimento e avaliação preliminar da estabilidade de formulações cosméticas acrescidas de extrato comercial de Trichilia catigua Adr. Juss (e) Ptychopetalum olacoides Bentham. Revista de Ciências Farmacêuticas Básica e Aplicada 2008; 29:181-96. 